\title{
Anti-PD-1 antibodies as a salvage therapy for patients with diffuse large $B$ cell lymphoma who progressed/relapsed after CART19/20 therapy
}

\author{
Chunmeng Wang ${ }^{1}$, Fengxia Shi ${ }^{1}$, Yang Liu ${ }^{1}$, Yajing Zhang ${ }^{1}$, Liang Dong ${ }^{1}$, Xiang Li ${ }^{1}$, Chuan Tong ${ }^{1}$, Yao Wang ${ }^{1}$,
} Liping $\mathrm{Su}^{2}$, Jing $\mathrm{Nie}^{1 *}$ and Weidong $\mathrm{Han}^{1 *}$

\begin{abstract}
CD19-directed chimeric antigen receptor T cell (CART19) therapy is efficient and approved for relapsed/refractory diffuse large B cell lymphoma (DLBCL). To increase durable antitumor response, we previously designed tandem CART19/20 cells and shown longer progression-free survival. However, a proportion of CART19/20-treated patients will finally progress and require salvage therapies. In this study, we analyzed data from five patients with relapsed/ refractory DLBCL who had disease progression or relapse following CART19/20 therapy and then treated with PD1-blocking antibodies as salvage therapy. Two of five patients acquired complete remissions after anti-PD-1 therapy, including one patient remained ongoing remission for more than 21 months. One patient achieved a partial remission, and the other two had progressive diseases. No $\geq$ grade 3 treatment-related adverse events or cytokine release syndrome was observed. Immunohistochemistry of tumor specimens revealed higher PD-1/PD-L1 expression in responsive patients with anti-PD-1 therapy as compared to that in non-responders. After anti-PD-1 treatment, circulating T cells were activated in responders, and no significant expansion of CART19/20 cells was detected. Our data suggest that PD-1 blockade therapy can be active in patients with relapsed/refractory DLBCL after failure of CART cell therapy who had PD-L1 expression in tumor cells and high PD-1 level in tumor-infiltrated T cells.
\end{abstract}

Keywords: DLBCL, Anti-PD-1, CART, Salvage therapy, PD-1/PD-L1

\section{To the Editor,}

Diffuse large B cell lymphoma (DLBCL) is the most common type of aggressive non-Hodgkin lymphoma (NHL) worldwide, accounting for $30-40 \%$ of adult NHL [1]. Although approximately $60-70 \%$ of patients are cured with standard frontline therapy, the remaining patients are refractory to frontline therapy or relapse

\footnotetext{
*Correspondence: nnij2002@163.com; hanwdrsw69@yahoo.com

${ }^{\dagger}$ Jing Nie and Weidong Han jointly supervise this work.

${ }^{\dagger}$ Chunmeng Wang and Fengxia Shi are co-first author.

${ }^{1}$ Department of Bio-Therapeutic, the First Medical Centre in Chinese PLA General Hospital, Beijing, China

Full list of author information is available at the end of the article
}

after complete remission [2, 3]. Patients with relapsed/ refractory DLBCL respond poorly to other line of chemotherapy, and few patients experience long-term survival [4]. CD19-targeted CAR T cell (CART19) therapy has remarkably improved the outcome of aggressive $\mathrm{B}$ cell lymphoma, and $52-83 \%$ of patients had a response including $40-58 \%$ achieving a complete remission, with a median progression-free survival of 5.9 months $[5,6]$. In order to potentiate the long-term efficiency of CART therapy, we previously designed and reported that tandem CART19/20 had a robust antitumor activity, and $64 \%$ of patients resulted in durable response for more than one year [7]. Despite the encouraging results, a part original author(s) and the source, provide a link to the Creative Commons licence, and indicate if changes were made. The images or other third party material in this article are included in the article's Creative Commons licence, unless indicated otherwise in a credit line to the material. If material is not included in the article's Creative Commons licence and your intended use is not permitted by statutory regulation or exceeds the permitted use, you will need to obtain permission directly from the copyright holder. To view a copy of this licence, visit http://creativecommons.org/licenses/by/4.0/. The Creative Commons Public Domain Dedication waiver (http://creativeco mmons.org/publicdomain/zero/1.0/) applies to the data made available in this article, unless otherwise stated in a credit line to the data. 
Table 1 Baseline clinical characteristics and post-anti-PD-1 outcomes

\begin{tabular}{|c|c|c|c|c|c|}
\hline Patient no. & 1 & 2 & 3 & 4 & 5 \\
\hline Age (years) & 54 & 40 & 41 & 38 & 35 \\
\hline Sex & M & $\mathrm{F}$ & $\mathrm{F}$ & M & $\mathrm{F}$ \\
\hline $\begin{array}{l}\text { ECOG performance } \\
\text { status }\end{array}$ & 0 & 2 & 1 & 0 & 2 \\
\hline Diagnosis/stage & DLBCL/IV & $\mathrm{DLBCL} / \mathrm{IV}$ & DLBCL/III & DLBCL/IV & DLBCL/III \\
\hline Disease status $^{1}$ & Relapsed & Primary refractory & Primary refractory & Relapsed & Primary refractory \\
\hline Target lesion & Bilateral parotid nodule & $\begin{array}{l}\text { Bone marrow, spleen, } \\
\text { lymph nodes ( } 9 \\
\text { regions) }\end{array}$ & $\begin{array}{l}\text { Lymph nodes ( } 2 \\
\text { regions) }\end{array}$ & Bone, lymph node & Lymph node \\
\hline Prior system regimens & $\begin{array}{l}\text { RCHOP } \times 5, \text { RDICE } \times 3, \\
\text { RGEMOX } \times 9 \\
\text { RMTX } \times 2, \text { RAD } \times 6, \\
\text { BEACOPP } \times 2\end{array}$ & $\begin{array}{l}\text { RCHOP } \times 8, \text { DHAP } \times 4, \\
\text { CART19 }\end{array}$ & $\begin{array}{l}\mathrm{CHOPE} \times 4, \mathrm{RDICE} \times 6, \\
\mathrm{RDHAP} \times 4, \mathrm{IR} \times 2\end{array}$ & $\begin{array}{l}\text { RCHOPE } \times 2, A B V D \times 3 \\
\text { DICE } \times 4, E S H A P \times 7 \\
\text { BEAM } \times 2, \text { R2 } \times 6\end{array}$ & REPOCH $\times 8$, GEMOX $\times 2$ \\
\hline Prior RT & Yes & No & No & No & No \\
\hline Prior ASCT & Yes & No & No & No & No \\
\hline Prior CD19/CD20 CAR-T & Yes & Yes & Yes & Yes & Yes \\
\hline Best response & $C R$ & $C R$ & $P R$ & $C R$ & PD \\
\hline Final response & PD & PD & PD & PD & PD \\
\hline PFS (months) & 6 & 6 & 5 & 3 & 3 \\
\hline $\begin{array}{l}\text { Percentage of PD-L1+ } \\
\text { expression }^{2}\end{array}$ & 0 & 0 & $30 \%$ & $70 \%$ & 0 \\
\hline $\begin{array}{l}\text { Percentage of PD-L1+ } \\
\text { expression }^{3}\end{array}$ & $30 \%$ & 0 & $40 \%$ & $80 \%$ & 0 \\
\hline $\begin{array}{l}\text { Percentage of PD-1 } \\
\text { expression }^{2}\end{array}$ & 0 & 0 & $20 \%$ & 0 & 0 \\
\hline $\begin{array}{l}\text { Percentage of PD- } 1^{+} \\
\text {expression }\end{array}$ & $80 \%$ & $5 \%$ & $60 \%$ & $60 \%$ & 0 \\
\hline \multicolumn{6}{|l|}{ Anti-PD-1 therapy } \\
\hline $\begin{array}{l}\text { Antibody type (treat- } \\
\text { ment cycle) }\end{array}$ & Sintilimab (12) & Camrelizumab (1) & Sintilimab (5) & Camrelizumab (24) & $\begin{array}{l}\text { Sintilimab } \\
\text { (2) }\end{array}$ \\
\hline Best response & $C R$ & PD & PR & $C R$ & $\mathrm{PD}$ \\
\hline Final response & PD & PD & PD & $C R$ & PD \\
\hline PFS (months) & 10.1 & 0.63 & 3.3 & 21.8 & 1 \\
\hline OS (months) & $\mathrm{NE}$ & 16.2 & $\mathrm{NE}$ & $\mathrm{NE}$ & 15.6 \\
\hline TrAE (grade) & $\begin{array}{l}\text { Increased transami- } \\
\text { nase (1) }\end{array}$ & None & $\begin{array}{l}\text { Fever (2), leukocytope- } \\
\text { nia (2) }\end{array}$ & Fever (1), rash (1) & None \\
\hline
\end{tabular}

ASCT, autologous stem-cell transplantation; ABVD, doxorubicin, bleomycin, vindesine, dacarbazine; BEACOPP, bleomycin, etoposide, doxorubicin, cyclophosphamide, vindesine, procarbazine, prednisone; BEAM, carmustine, etoposide, cytarabine, melphalan; CHOPE, cyclophosphamide, vindesine, doxorubicin, etoposide, prednisone; DHAP, cisplatin, cytarabine, dexamethasone; ESHAP, rituximab, etoposide, vindesine, doxorubicin, cyclophosphamide, prednisone; GEMOX, gemcitabine, oxaliplatin; RCHOP, rituximab, cyclophosphamide, vindesine, doxorubicin, prednisone; RMTX, rituximab, methotrexate; RAD, rituximab, cytosine arabinoside, dexamethasone; RDHAP, rituximab, cisplatin, cytarabine, dexamethasone; RDICE, rituximab, ifosfamide, cisplatin, etoposide, dexamethasone; REPOCH, rituximab, etoposide, vindesine, doxorubicin, cyclophosphamide, prednisone; RGEMOX, rituximab, gemcitabine, oxaliplatin; RFC, rituximab, fludarabine, cyclophosphamide; R2, rituximab combined with lenalidomide; DLBCL, diffuse large B cell lymphoma; ECOG, Eastern Cooperative Oncology Group; GCB, germinal center B cell; PFS, progression-free survival; TrAE, treatment-related adverse events

${ }^{1}$ Primary refractory, non-response or relapse within 3 months of frontline therapy

${ }^{2}$ These data were collected prior to CART19/20 therapy

${ }^{3}$ These data were collected after failure of CART19/20 therapy

of patients eventually experienced disease progression or relapse after CART19/20 therapy. Effective treatment strategies for those patients post-CART19 or CART19/20 failure are imperative but limited.

Programmed cell death-1 (PD-1) is a key immune checkpoint that suppresses $\mathrm{T}$ cell-mediated immune response. Emerging evidence has suggested aberrant PD-L1 expression on tumor cells elicited inhibitory signals, caused CAR T cell exhaustion and impaired tumor cell killing, regarding as one mechanism in the setting of relapses after CART therapy [8]. The combination of CART therapy and PD-1 blockade therapy has been 
conducted in preclinical models and clinical trials, in order to escalate CAR T cell function and enhance the antitumor efficacy $[9,10]$. Moreover, engineered CAR $\mathrm{T}$ cells producing $\mathrm{PD}-1$-neutralizing $\mathrm{scFv}$ displayed improved survival in mouse solid tumor models [11]. However, the effect of PD-1 blockade therapy in patients with B cell lymphoma who failed CAR $T$ cell therapy was not clear. Here, we reported the efficacy and biological characteristics of five DLBCL patients who received PD1-blocking antibody as a salvage treatment after failure of CART19/20 cell infusion.

Between May 1 and September 21, 2019, five patients with relapsed/refractory DLBCL and recurrent/progressive lymphoma after tandem CART19/20 (TanCAR7 $\mathrm{T}$ cells) therapy (NCT03097770) [7] were enrolled. The retrospective study was approved by the Ethics Committee of Chinese PLA General Hospital and conducted in accordance with principles of the Declaration of Helsinki. Informed consent was obtained from all patients. Patients were at a median age of 41 years (range 38-55 years) and had primary refractory $(n=3)$ or relapsed $(n=2)$ non-germinal center B cell DLBCL, and three patients had extranodal lesions. All patients had received three or more previous regimens (range 3 to 9), and CART19/20 therapy was the most recent treatment with a median progression-free survival (PFS) of 5 months (Table 1). After failing CART therapy, patients received PD-1-blocking antibody (sintilimab or camrelizumab) at $200 \mathrm{mg}$ every 2 weeks as a salvage treatment. Treatment continued until disease progression or unacceptable toxicity occurred. Patients with sustained CRs received consolidate treatment per 4 weeks. As of May 1 , 2021, the median follow-up was 21.8 months, one patient remained on treatment, and other four discontinued therapy because of disease progression.

Overall, three of five patients experienced treatmentrelated adverse events, including fever in two patients, rash, leukocytopenia and increased transaminase in one patient, respectively (Table 1 ). No $\geq 3$ grade toxicities or treatment-related deaths occurred. Besides, cytokine release syndrome (CRS) was not observed after anti-PD-1 antibody therapy in all patients, although they had received infusion of CART19/20 cells within six months.

The antitumor response was evaluated using FDGPET-CT at baseline and every 2 to 3 months, based on the Revised Response Criteria for Malignant Lymphomas (Lugano classification). As shown in Table 1 and Fig. 1a, $\mathrm{b}$, three of the five patients achieved objective responses after PD-1 blockade therapy, including two CRs and one PR; the other two patients had progressive diseases and died on 15.6-16.2 months. UPN4 maintained durable CR till data cutoff date with response duration of 21.3 month, and PFS was 21.8 months. The baseline tumor in UPN1 was completely eliminated, while another new lesion occurred and evaluated as disease progression after 10 months (Additional file 1: Fig. S1).

As detected by immunohistochemical staining, tumor cells from all five patients expressed CD19 and CD20 both prior to and after failure of CART19/20 therapy, with more $\mathrm{CD}^{+} \mathrm{T}$ cells in tumor microenvironment at relapse (Additional file 1: Fig. S2). The $\mathrm{H}$-scores for PD-1 and PD-L1 are listed in Additional file 1: Table S1. Interestingly, we observed significantly higher PD-1 expression in $\mathrm{CD}^{+} \mathrm{T}$ cells and more PD- $1^{+}$tumor cells in patients responding to anti-PD-1 treatment (UPN1, 3 and 4) compared to those without a response (UPN2 and 5; Fig. 1c, d, Table 1). Especially for UPN4 whose tumor cells strongly expressed PD-L1, PD-1 expression in tumor-infiltrated $\mathrm{CD}^{+}$cells was not detectable prior to CART19/20 cell infusion and increased to $60 \%$ when tumor relapsed; after two-month anti-PD-1 camrelizumab salvage treatment, he obtained a CR (Fig. 1e). After camrelizumab treatment, peripheral $\mathrm{T}$ cells were activated as increased percentage of IFN- $\gamma$-expressing $\mathrm{T}$ cells and decreased PD-1 level (Fig. 1f). Serum cytokine IL-6 and IL- 2 were elevated within 4 weeks, while only a tiny expansion of circulating CART19/20 cells occurred on 6 weeks (Fig. 1g, h). Increased levels of serum cytokines and $\mathrm{T}$ cell activation were also detected in UPN3 (Additional file 1: Fig. S3). Based on our results, at treatment failure of CART therapy, tumor PD-L1 expression was weakly upregulated, and tumor-infiltrated $\mathrm{T}$

\footnotetext{
(See figure on next page.)

Fig. 1 Clinical response to anti-PD-1 therapy and biological biomarker detection. a Anti-PD-1 treatment response of each patient and duration of response following anti-PD-1 salvage therapy. UPN1 had 100\% decrease in baseline tumor burden and another new lesion occurred, and evaluated as disease progression after 10 months. CR, complete response; PR, partial response; SD, stable disease; PD, progressive disease. $\mathbf{b}$ Percentage change of tumor burden after anti-PD-1 therapy compared to baseline level prior to anti-PD-1. $\mathbf{c}$, $\mathbf{d}$ Percentage of PD- $1^{+} \mathrm{CD} 3^{+}$cells in tumor-infiltrated $\mathrm{CD}^{+}{ }^{+}$cells (c) or PD-L1 ${ }^{+}$cells in CD19 and CD20 tumor cells (d) from all five patients before CART19/20 cell infusion and after disease progression or relapse post-CART therapy. Responses to anti-PD-1 salvage therapy were shown. e PET/CT imaging for UPN4 before anti-PD-1 and 2 months after anti-PD- 1 therapy. $\mathbf{f}$ Percentage of IFN- $\gamma^{+} \mathrm{CD} 8^{+}$cells, IFN- $\gamma^{+} \mathrm{CD} 4^{+}$cells, PD- $1^{+} \mathrm{CD} 8^{+}$cells and PD- ${ }^{+} \mathrm{CD} 4^{+}$cells in peripheral blood prior to anti-PD-1 and 14 days after anti-PD-1 treatment in UPN4 by flow cytometry. $\mathbf{g}$ The absolute number of CART19/20 cells in UPN4 by PCR. $\mathbf{h}$ Serum cytokine levels in UPN4 following PD-1 blockade therapy. UPN, unique patient number
} 

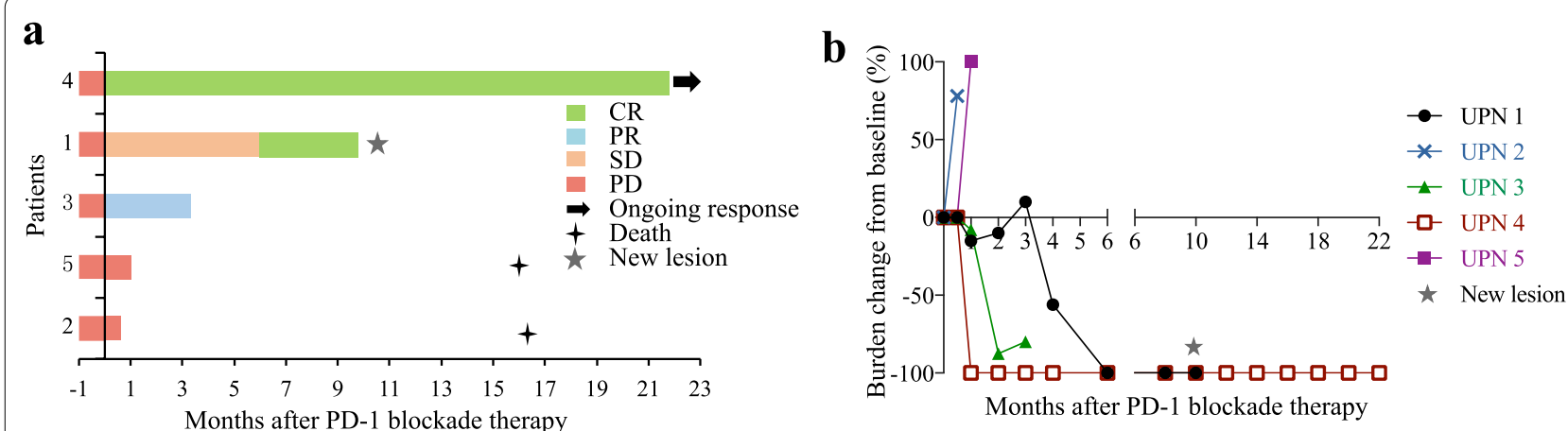

c

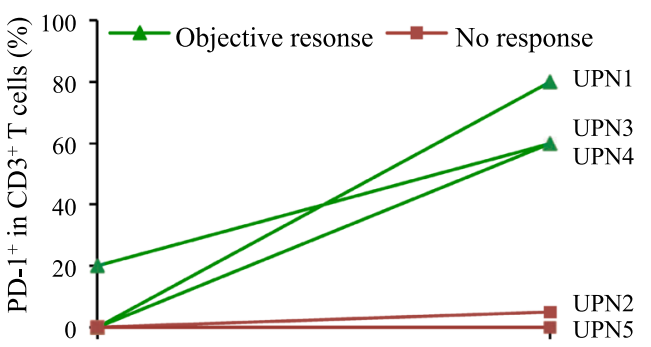

Before CART19/20

Before PD-1 blockade therapy cell infusion (After CART19/20 failure)

e UPN4
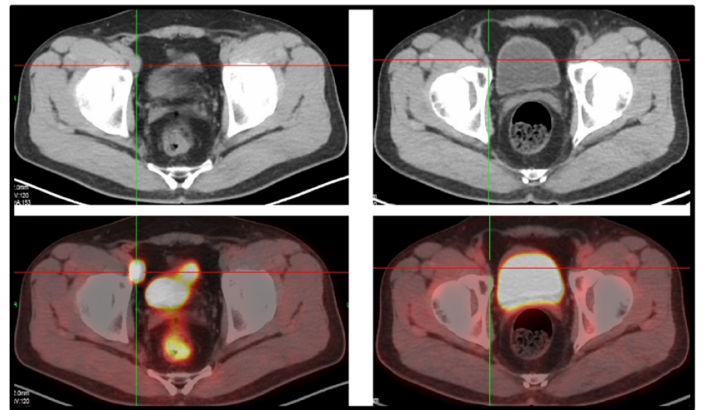

Before PD-1 blockade therapy

2 months after therapy

g

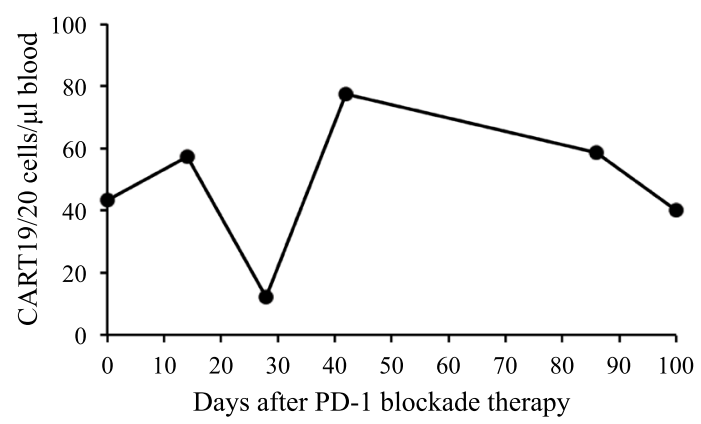

d

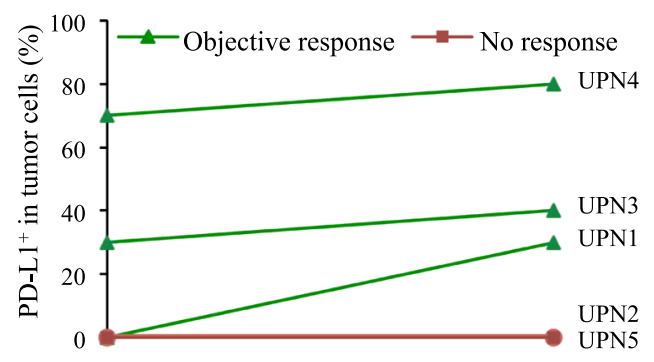

Before CART19/20 cell infusion (After CART19/20 failure)

f UPN4

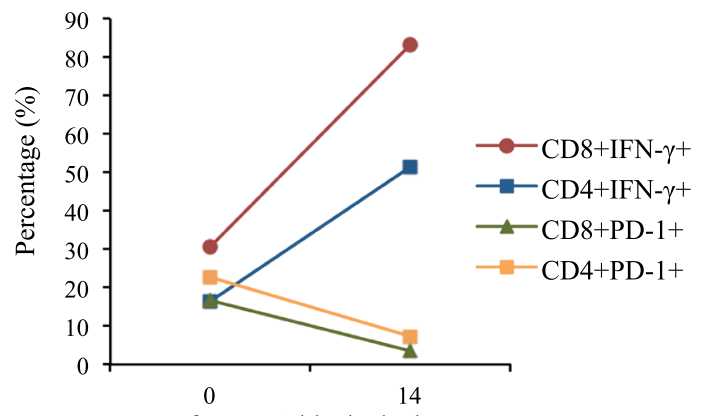

Days after PD-1 blockade therapy

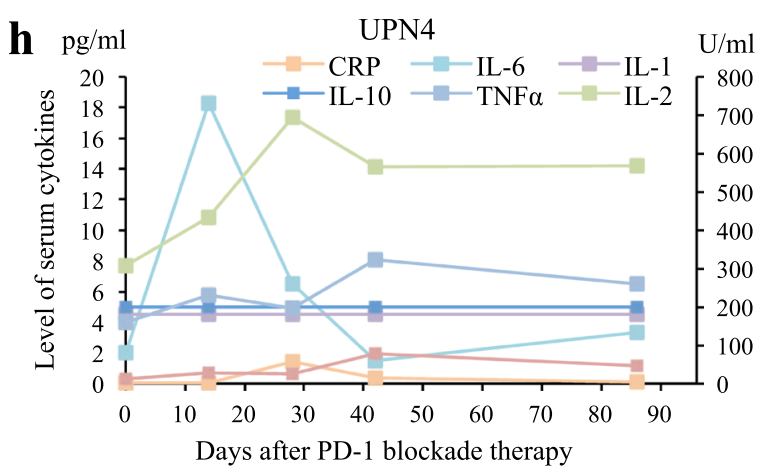

Fig. 1 (See legend on previous page.) 
cells in some patients were highly exhausted and might have responsiveness to PD-1 blockade therapy.

Till now, effective salvage treatments for patients with aggressive DLBCL who experience relapsed/refractory lymphoma after CART19 therapy are urgently needed. Infusion of different CART cells, such as CD28-based CART19, CD19-PD-1/CD28-CAR-T, or a second CART19 infusion had been used, achieving an objective response of $33-52 \%$ [12-14]. Elise A. Chong et al. reported a significant antitumor response of pembrolizumab in one case with DLBCL and progressive lymphoma after CART19, with expansion of CART19 cells following pembrolizumab [15]. In the present study, among five patients after failing CART19/20 therapy, three had objective responses (2 CRs and 1 PR) with a salvage therapy of anti-PD-1 antibodies, and no serious toxicities experienced.

Loss of tumor antigens and emergence of an immunosuppressive tumor microenvironment contributed to the adaptive resistance to CART immunotherapy [8]. In this study, none of the five patients lost tumor antigen expression at disease recurrence or progression postCART19/20 therapy, while PD- 1 expression in $\mathrm{CD}^{+} \mathrm{T}$ cells was dramatically elevated in three patients. Notably, these three patients acquired a response to antiPD-1 and UPN4 whose tumor cells had the highest PD-L1 expression (80\%) achieved a long-lasting remission. Moreover, the antitumor effect of anti-PD-1 salvage therapy might not be relied on enhancing the efficacy of CART cells, since we did not observe significant expansion of CART19/20 cells and related elevation of serum cytokines. However, after CART therapy these three patients' lymphomas changed into "hot tumor" and responded to anti-PD-1. Thus, PD-1/PD-L1 pathway might be crucial in controlling the effectiveness and overcoming the resistance to CART therapy.

Together, our data suggest that PD-L1 expression in tumor cells and high PD-1 level in T cells might be potential biomarkers to predict the outcome of anti-PD-1 antibodies in relapsed/refractory DLBCL and PD-1 blockade therapy is recommended for patients in this setting after failure of CART therapy. To further increase clinical response, we are planning to conduct a phase I/II clinical trial of anti-PD-1-based combination therapy in patients with DLBCL failing to response to CART therapy.

\section{Supplementary Information}

The online version contains supplementary material available at https://doi. org/10.1186/s13045-021-01120-3.

Additional file 1. Figure S1. PET/CT imaging for UPN1. Figure S2. Immunohistochemistry in tumor samples from all five patients. Figure S3. Biological biomarker detection from blood samples. Table S1. H-scores for PD-1 and PD-L1 in patients before CART19/20 therapy and after failure of CART19/20.

\section{Acknowledgements}

The authors are grateful for Dr Xiaojing An for the pathological analysis and the nurses and staff in the Department of Bio-therapeutic at the First Medical Centre in the Chinese PLA General Hospital.

\section{Authors' contributions}

$C W, F S, L D, X L$ and $C T$ were involved in the acquisition of data; JN, YL, YW and LS were involved in analysis and interpretation of data; JN and CW were involved in writing and revision of the manuscript; WH was involved in supervision. All authors read and approved the final manuscript.

\section{Funding}

This work was funded under the auspices of the National Key Research and Development Program of China (2019YFC1316205 to JN), National Natural Science Foundation of China (31991171, 81872479, 31870873, 82022057, 81830002 and 81903153), and with Fostering Funds from the Chinese PLA General Hospital's National Excellent Young Scholar Science Fund (2020-JQPY-001).

\section{Availability of data and materials}

Additional data are provided in the data supplement available online. Individual participant data will be shared by the corresponding author on reasonable request.

\section{Declarations}

\section{Ethics approval and consent to participate}

The study was approved by the Ethics Committee of Chinese PLA General Hospital, in accordance with the ethical principles of Good Clinical Practice and the Declaration of Helsinki. All patients provided written informed consent.

\section{Consent for publication}

All authors approved the final manuscript for publication.

\section{Competing interests}

All authors declared no potential conflict of interest.

\section{Author details}

${ }^{1}$ Department of Bio-Therapeutic, the First Medical Centre in Chinese PLA General Hospital, Beijing, China. ${ }^{2}$ Department of Hematology, Shanxi Cancer Hospital, Taiyuan, Shanxi, China.

Received: 27 May 2021 Accepted: 29 June 2021

Published online: 05 July 2021

References

1. Dunleavy K, Erdmann T, Lenz G. Targeting the B-cell receptor pathway in diffuse large B-cell lymphoma. Cancer Treat Rev. 2018;65:41-6.

2. Pfreundschuh M, Kuhnt E, Trumper L, Osterborg A, Trneny M, Shepherd L, Gill DS, Walewski J, Pettengell R, Jaeger U, et al. CHOP-like chemotherapy with or without rituximab in young patients with good-prognosis diffuse large-B-cell lymphoma: 6-year results of an open-label randomised study of the MabThera International Trial (MInT) Group. Lancet Oncol. 2011;12(11):1013-22.

3. Feugier P, Van Hoof A, Sebban C, Solal-Celigny P, Bouabdallah R, Ferme C, Christian B, Lepage $\mathrm{E}$, Tilly H, Morschhauser $\mathrm{F}$, et al. Long-term results of the R-CHOP study in the treatment of elderly patients with diffuse large B-cell lymphoma: a study by the Groupe d'Etude des Lymphomes de I'Adulte. J Clin Oncol. 2005;23(18):4117-26.

4. Friedberg JW. Relapsed/refractory diffuse large B-cell lymphoma. Hematol Am Soc Hematol Educ Program. 2011;2011:498-505.

5. Locke FL, Ghobadi A, Jacobson CA, Miklos DB, Lekakis LJ, Oluwole OO, Lin Y, Braunschweig I, Hill BT, Timmerman JM, et al. Long-term safety and activity of axicabtagene ciloleucel in refractory large B-cell lymphoma (ZUMA-1): a single-arm, multicentre, phase 1-2 trial. Lancet Oncol. 2019;20(1):31-42 
6. Schuster SJ, Bishop MR, Tam CS, Waller EK, Borchmann P, McGuirk JP, Jager U, Jaglowski S, Andreadis C, Westin JR, et al. Tisagenlecleucel in adult relapsed or refractory diffuse large B-cell lymphoma. N Engl J Med. 2019;380(1):45-56.

7. Tong C, Zhang Y, Liu Y, Ji X, Zhang W, Guo Y, Han X, Ti D, Dai H, Wang C, et al. Optimized tandem CD19/CD20 CAR-engineered T cells in refractory/relapsed B-cell lymphoma. Blood. 2020;136(14):1632-44.

8. Sharma P, Hu-Lieskovan S, Wargo JA, Ribas A. Primary, adaptive, and acquired resistance to cancer immunotherapy. Cell. 2017;168(4):707-23.

9. John LB, Devaud C, Duong CP, Yong CS, Beavis PA, Haynes NM, Chow MT, Smyth MJ, Kershaw MH, Darcy PK. Anti-PD-1 antibody therapy potently enhances the eradication of established tumors by gene-modified T cells. Clin Cancer Res. 2013;19(20):5636-46.

10. Kato D, Yaguchi T, Iwata T, Katoh Y, Morii K, Tsubota K, Takise Y, Tamiya M, Kamada H, Akiba H, et al. GPC1 specific CAR-T cells eradicate established solid tumor without adverse effects and synergize with anti-PD-1 Ab. Elife. 2020;9:e49392.

11. Ping Y, Li F, Nan S, Zhang D, Shi X, Shan J, Zhang Y. Augmenting the effectiveness of CAR-T cells by enhanced self-delivery of PD-1-neutralizing scFv. Front Cell Dev Biol. 2020;8:803.
12. Chow VA, Gopal AK, Gauthier J, Tseng YD, Turtle CJ, Maloney DG, Shadman M. Axicabtagene ciloleucel for relapsed or refractory lymphoma after prior treatment with a different CD19-directed CAR T-cell therapy. Blood Adv. 2020;4(19):4869-72.

13. Liang Y, Liu H, Lu Z, Lei W, Zhang C, Li P, Liang A, Young KH, Qian W. CD19 CAR-T expressing PD-1/CD28 chimeric switch receptor as a salvage therapy for DLBCL patients treated with different CD19-directed CAR T-cell therapies. J Hematol Oncol. 2021;14(1):26.

14. Gauthier J, Bezerra ED, Hirayama AV, Fiorenza S, Sheih A, Chou CK, Kimble EL, Pender BS, Hawkins RM, Vakil A, et al. Factors associated with outcomes after a second CD19-targeted CAR T-cell infusion for refractory B-cell malignancies. Blood. 2021;137(3):323-35.

15. Chong EA, Melenhorst JJ, Lacey SF, Ambrose DE, Gonzalez V, Levine BL, June $\mathrm{CH}$, Schuster SJ. PD-1 blockade modulates chimeric antigen receptor (CAR)-modified T cells: refueling the CAR. Blood. 2017;129(8):1039-41.

\section{Publisher's Note}

Springer Nature remains neutral with regard to jurisdictional claims in published maps and institutional affiliations.
Ready to submit your research? Choose BMC and benefit from:

- fast, convenient online submission

- thorough peer review by experienced researchers in your field

- rapid publication on acceptance

- support for research data, including large and complex data types

- gold Open Access which fosters wider collaboration and increased citations

- maximum visibility for your research: over 100M website views per year

At BMC, research is always in progress.

Learn more biomedcentral.com/submissions 